\title{
Regional Patterns in Dumping Sites in Poland - Analysis in Context of the New "Sustainable" Waste Policy
}

\author{
Elżbieta Antczak* \\ Department of Spatial Econometrics, Faculty of Economics and Sociology, University of Lodz, Poland
}

Received: 18 January 2019

Accepted: 12 April 2019

\begin{abstract}
This study examined the changes in spatial distribution of dumping sites in Polish districts over the 2009-2016 in the context of the new waste management policy. The regional patterns of dumping sites were identified using spatial concentration measures (location quotient, spatial Gini) and the spatial interactions were explored with univariate and bivariate Moran's I statistics. This analysis also examined the extent to which spatial interactions took place. The number of legal and illegal (existing and removed) dumping sites was measured per $100 \mathrm{~km}^{2}$ of the total area of districts. Results indicated that spatial concentration of illegal dumping sites increased noticeably in the transition period of the legislation changes $82 \%$ of Polish districts contained illegal dumping sites). A considerably strong regional concentration of illegal dumps was observed in rural areas, forests, northern parts of Poland and densely populated districts. Positive global Moran's I statistic proved the presence of clusters of districts with similar levels of dumping sites. The local bivariate spatial analysis investigated the relation between the number of waste sites in one location and the lag factor of dumps in nearby areas. This empirical study provides useful data to the relevant decision makers and local governments for urban planning.
\end{abstract}

Keywords: municipal waste, uncontrolled dumping sites, spatial concentration, spatial autocorrelation and correlation, Polish districts

\section{Introduction}

Compared to the European Union average (UE-28), Poland currently has a lower amount of municipal waste generated per person (in $2017,310 \mathrm{~kg}$ per person in Poland and $486 \mathrm{~kg}$ per person in the UE-28). However, the volume of waste collected in the

*e-mail: elzbieta.antczak@uni.lodz.pl country is underestimated by $30 \%$, and therefore is significantly greater than what is statistically reported [1-3]. According to studies on the ecological behaviour of Poles (which are carried out regularly at the end of each year by the Ministry of the Environment, residents disposed of waste by burning it in domestic boilers (64\%) and dumping it in forests $(28 \%)$, on neighbours' land $(14 \%)$, and in other uncontrolled dumping places (26\%) [4]. Based on the Polish Local Data Bank, approximately 2,000 new uncontrolled dumping sites emerged in 2016. This pattern is 
attributable to low ecological awareness and ineffective waste management policy, i.e., charging system as well as waste management policy $[3,5]$.

Understanding the problem of dumping sites is crucial for effective, sustainable waste management in the context of a circular economy transition [6] and sustainable development policy [7]. Dumped waste has serious implications for the environment [8, 9] and quality of life [10]. The uncontrolled waste sites occupy excavations or geological depressions without additional specific preparation, and therefore wastes contaminate both soil and water [11-13]. Moreover, illegal dump sites serve as magnets for additional dumping or other criminal activities [14], resulting in damage to local landscapes and surrounding property values [15]. Finally, it constitutes blight, which lowers real estate values, limits tourism, and compromises the safety of communities [16].

Polish literature dealing with waste data has been rather limited to date mainly due to the lack of a comprehensive waste database [17, 18]. Most studies have generally focused on the environmental pollution caused by waste dumping sites or remaining disposals $[19,20]$. Moreover, some research has concentrated on identifying the location of illegal landfills at a microgeographical scale, e.g., in forests, on the edge of a wood, in areas bordering an arable field or a meadow, along a stream, in areas partially immersed in water or occasionally flooded, along tourist routes and roads, and to a lesser extent in the vicinity of buildings, national parks, and Natura 2000 [21-23]. Other studies have developed methodologies for identifying illegal landfills [24-26].

This research contributes to the literature by providing the first attempt to explore the regional distribution of dumping sites (legal and illegal) in Polish districts, while taking into account the structure of deposition sites and spatial aspects of variability. In particular, I investigate the extent to which spatial interactions (autocorrelations and correlations) take place and determine the quantity of dumping sites at this level of territorial aggregation. Such knowledge is especially relevant because districts can be directly affected by a top-down waste governmental policy, for example the National Waste Management Plan 2022 [27], and legal bottom-up acts on maintaining cleanliness and order in municipalities [28]. No studies have so far been conducted to examine the disproportionate spatial distribution of dumping sites, or to better understand spatiotemporal changes in the types of deposition sites. My findings indicate that districts, in the vicinity of which no controlled municipal waste sites were recorded, are characterized by above-average concentrations of illegal landfills. Moreover, it seems illegal dumping sites are stochastic in their nature in that removal of illegal dumping sites affects the emergence of new ones.

\section{Legislative Changes in Polish 'Sustainable' Waste Policy}

Since 2013, the new Act on maintaining cleanliness and order in municipalities has laid responsibility on communes for municipal waste collection and disposal (a commune, municipality, LAU-2, in Poland is the lowest local administrative unit. Poland currently has app. 2500 communes). Since then, communes are required to organize waste collection and maintain cleanliness, including removing illegal landfills, in their administrative area. Under the act on management of packaging and packaging waste (13 June 2013) as well as the new National Waste Management Plan 2022, the new legislation is supposed to introduce reforms to improve practices and help meet recycling targets of European Union waste policy (European Landfill Directive 99/31/EC). However, the problem of municipal waste management was essentially split between the municipality (as a rule) and the real property owners (as a matter of exception). It is the real property owner who is responsible for segregating waste according to specific categories. Moreover, that owner is required to pay a fee, the amount of which is mainly determined by the municipality. The municipal council determines this fee by way of a resolution that is an act of local law [29]. A significant characteristic of this fee is that it derives from public law (it is adjusted to reflect either: the number of people living in a household as declared by the owner; the number of square metres covered by the property; or the number of cubic metres of water used by the household per month), and therefore it varies across regions. Some municipalities charge as little as 3 Polish Zloty (PLN; approximately $\$ 0.82$ ) per person per month, while others charge 20 PLN (approximately \$5.50). The standard charge is also affected by the declaration of waste segregation by the householder, i.e., if property owners declare that they have separated recyclable waste materials, they pay a considerably lower disposal fee, which in some municipalities can be as low as $50 \%$ of the regular charge. Thus, to avoid paying a higher waste disposal costs, some householders falsely declare that they recycle their waste while in reality they do not [1]. Especially since the new scheme is still in its early stages and therefore, is not yet as developed as in many other EU countries, monitoring such abuses of the system represents quite a challenging task $[30,31]$.

Such a spatial process might also be a consequence of either the unlimited number of landfill sites or their location within administrative boundaries as long as the company fulfills the conditions required by law. Unfortunately, the European Union Commission proposes to ramp up recycling by 2030 by imposing a ban on landfill for separately collected waste. Moreover, reducing the amount of biodegradable municipal solid 
waste disposed of in landfills is determined by law. Meanwhile, Polish waste management essentially relies on controlled waste landfilling. According to the latest Eurostat data, on average, $50 \%$ of the collected waste is pre-sorted and disposed of by landfilling in Poland (23\% in EU-28). Moreover, based on the Polish Local Data Bank, the area of a landfill was approximately $18,000 \mathrm{~km}^{2}$ in 2016 (app. 6\% of total country area), and the number of controlled dumping sites exceeded 320. The main reasons for landfilling are insufficient number of waste collection and transport companies and networks running or building waste processing facilities. Each region must have at least one regional municipal waste treatment plant, but it can also have two or even more such plants [29]. Meanwhile, in Poland, only 300 such entities exist, and these are able to process merely $33 \%$ of the total collected municipal waste [32]. In practice, such as the fact that municipal waste from the most extreme areas is transported to the regional municipal waste treatment plant providing services for the needs of a specific region, while the distance to such a plant can be greater than the distance to the plant in the neighbouring region. Therefore, preserving the proximity rule and disposing of waste at the source is at least doubtful. This is also because of the lack of Selective Municipal Waste Collection Points and household waste recycling centers. Such places have not yet been established in approximately $30 \%$ of the communes in Poland [33]. For example, in 2016, there were only seven municipal waste (wasteto-energy) incineration plants in Poland, while there are over 450 such facilities in Europe (72 plants in Germany and approximately 130 in France). Polish management of municipal waste is based on specific market mechanisms. Therefore, under competitive market conditions, waste management companies consider profit maximization when making decisions regarding site location, and do not sufficiently consider inequalities caused by the accumulation of these sites within a geographical location. Therefore, the identification of spatial relationships is an integral part of waste processes in Poland because of garbage transport to treatment facilities [32, 34] and the regional heterogeneity of determinates of waste generation $[31,35]$.

Despite the implementation of innovative methods of waste management in Polish municipalities, effective enforcement of these methods is not a simple task. Systematic approaches to waste management are lacking, and there are not enough waste recovery and recycling plants. The main problem that needs to be addressed is the disposal of waste during the transition period, between the closure of landfill sites and launching of waste treatment facilities. Currently, both legal and illegal landfill sites pose a problem in Poland and therefore, the rising concentration of dumps might be an effect of the legislative changes.

\section{Material and Methods}

\section{Data}

The present investigation was carried out in 380 Polish districts (in the Local Administrative Unit classification of the European Union, "regions" at a detailed level refers to districts, LAU-1, whereas LAU-2 is a commune). A district was chosen as the unit of analysis for this study because it is the smallest geographical unit for which waste data are reliable and fully available. This is because the range of operations of waste facilities includes territory of more than one commune, and the number of waste treatment facilities necessitates the aggregation of the collected litter at a higher level, i.e., at least at the level of districts (more details are presented in Section 2). Such a system generates problems with the availability of accurate waste data [18].

The analysis was based on the number of controlled and uncontrolled dumping sites (existing as of December 31 and removed during a year) per $100 \mathrm{~km}^{2}$ of the area of districts from 2009 to 2016, collected from the Polish Local Data Bank in the Central Statistical Office (CSO). Statistics of these data are summarized in Table 1.

\section{Methods}

Firstly, to analyze the regional distribution of legal (controlled) and illegal (uncontrolled) dumping sites in Polish districts, location quotient and spatial Gini coefficient were used. The location quotient $(L Q)$ was calculated according to [36]:

$$
L Q_{i s}=\frac{x_{i s} / x_{s}}{x_{i} / x}
$$

...where $i$ is the $i$-th district for $n=1, \ldots, 380 ; x_{s i}$ is the number of dumping places in the $i$-th district for $s$-th dumping site category, i.e., uncontrolled existing, uncontrolled removed and controlled $(s=1, \ldots, 3) ; x_{s}$ is the number of dumps for $s$-th category in all LAU-1; $x_{i}$ is the number of all $s$-th dumps in the $i$-th district; and $x$ is the total number of dumping sites in all districts in Poland (as a reference variable).

General information on spatial concentration, i.e., the degree of non-uniformity of spatial distribution, was obtained from the $L Q$ values calculated for each district and each year of the analysis separately. These data indicated that the share of dumps located in a region in a given landfill category was comparable with the general number of dumping sites in all categories in Poland. An $L Q$ of 1.00 implies that the relative proportion of dumping sites in the study area is similar to the average in Poland (reference area); $L Q<1.00$ implies that the relative proportion of dumping sites in a district is below the normal trend observed in the 
Table 1. Summary statistics of dumping sites in Polish districts $(n=380)$.

\begin{tabular}{|c|c|c|c|c|c|c|c|c|}
\hline Dumping sites & 2009 & 2010 & 2011 & 2012 & 2013 & 2014 & 2015 & 2016 \\
\hline \multicolumn{9}{|c|}{ Controlled (units per $100 \mathrm{~km}^{2}$ ) } \\
\hline Sum & 132 & 111 & 106 & 101 & 89 & 87 & 76 & 73 \\
\hline Mean & 0 & 0 & 0 & 0 & 0 & 0 & 0 & 0 \\
\hline Minimum & 0 & 0 & 0 & 0 & 0 & 0 & 0 & 0 \\
\hline Maximum & 8 & 8 & 8 & 8 & 8 & 8 & 8 & 8 \\
\hline Median & 0.2 & 0.2 & 0.2 & 0.2 & 0.1 & 0.1 & 0.1 & 0.1 \\
\hline Std. Dev. & 1 & 1 & 1 & 1 & 1 & 1 & 1 & 1 \\
\hline CV $(\%)$ & 169 & 189 & 198 & 209 & 236 & 245 & 259 & 270 \\
\hline \multicolumn{9}{|c|}{ Uncontrolled existing (noted on December 31 of each year; units per $100 \mathrm{~km}^{2}$ ) } \\
\hline Sum & 1073 & 982 & 510 & 529 & 928 & 622 & 537 & 622 \\
\hline Mean & 3 & 3 & 1 & 1 & 2 & 2 & 1 & 2 \\
\hline Minimum & 0 & 0 & 0 & 0 & 0 & 0 & 0 & 0 \\
\hline Maximum & 453 & 375 & 75 & 99 & 280 & 118 & 120 & 123 \\
\hline Median & 0.3 & 0.3 & 0.2 & 0.2 & 0.2 & 0.2 & 0.1 & 0.1 \\
\hline Std. Dev. & 24 & 20 & 5 & 6 & 17 & 8 & 8 & 9 \\
\hline CV (\%) & 834 & 770 & 358 & 444 & 690 & 457 & 559 & 523 \\
\hline \multicolumn{9}{|c|}{ Uncontrolled sites removed during a year (units per $100 \mathrm{~km}^{2}$ ) } \\
\hline Sum & 4169 & 3790 & 5595 & 4571 & 5867 & 5491 & 5815 & 6415 \\
\hline Mean & 11 & 10 & 15 & 12 & 15 & 14 & 15 & 17 \\
\hline Minimum & 0 & 0 & 0 & 0 & 0 & 0 & 0 & 0 \\
\hline Maximum & 512 & 440 & 775 & 431 & 795 & 626 & 1108 & 1658 \\
\hline Median & 0.4 & 0.5 & 0.5 & 0.4 & 0.4 & 0.4 & 0.5 & 0.6 \\
\hline Std. Dev. & 44 & 39 & 64 & 46 & 68 & 55 & 70 & 95 \\
\hline CV (\%) & 399 & 388 & 431 & 383 & 440 & 382 & 455 & 562 \\
\hline
\end{tabular}

Note: Std.Dev. -standard deviation, CV -coefficient of variation.

Source: own elaboration based on Polish Local Data Bank in CSO.

reference area; and $L Q>1.00$ implies that the relative proportion of dumping sites in a district is above the normal trend observed in the reference area. Moreover, the degree above 1.00 indicates the percentage above the national normal trend [37]. Regional disparities in the number of dumping sites were also confirmed by values of the relative Gini spatial concentration coefficient (for spatial data). The Gini index for regional relative concentration is a measure that captures the degree of heterogeneity across the spatial units, i.e., it represents the rate of spatial concentration of the dumping sites $s$ referring to $r$ districts. While regional variability quantifies differences between regional means, the concept of relative regional variability quantifies spatial aspects of variability according to the proportion of overall variability, which can be attributed to different regional levels [38]. Here, the spatial Gini index was applied, which was first proposed by Krugman [39] and later popularized by Kim et al. [40] and Ruiz-Valenzuela et al. [41]:

$$
G_{i s}=\frac{\Delta}{2 \cdot \overline{L Q} Q_{i s}}, \Delta=\frac{1}{n(n-1)} \sum_{i=1}^{n} \sum_{j=1}^{n}\left|L Q_{i s}-L Q_{j s}\right|
$$

...where $L Q$ is the location quotient, $\overline{L Q}$ is the average of $L Q \mathrm{~s}$ for the $s$-th category of dumps, $n$ is the number of districts, $i=1, \ldots, 380$, and $i, j$ is a concrete district.

The Gini coefficient (Eq. 2) was originally used for quantifying differences in income [42], but was reintroduced here as a spatial index to analyze the structure of regional density of dumping sites. The value of the Gini coefficient varies from 0 to 1 ; a value of 0 indicates that the distribution of dumping sites in a district $i$ corresponds to the national distribution, and a 
value approximating 1 implies that a district $i$ presents a strong concentration of dumping sites in a specific category.

Secondly, to explore the degree of clustering for dumping sites and examine the structure and intensity of spatial autocorrelation, the global Moran's I statistics was applied:

$$
I=\frac{\sum_{i=1}^{n} \sum_{j=1}^{n} w_{i j}\left(x_{i}-\bar{x}\right)\left(x_{j}-\bar{x}\right)}{\sum_{i=1}^{n}\left(x_{i}-\bar{x}\right)^{2}}
$$

...where $n$ is the number of districts; $x_{i}$ and $x_{j}$ are values of the variable $x$ in districts $i$ and $j$, respectively; is the average of the variable $x$ over all spatial units; and $w_{i j}$ represents the elements of spatial weights matrix $W$, which measures the strength of the relationship between two districts. For variable $x$ of observed values $x_{i}$ in $i$-th different districts, having weights matrix $W$ standardized in rows. This means that each element in the $i$-th row is divided by the sum of values in that row. Elements of the row-standardized matrix take values between zero and one. The sum of values in a row is always one [43]. To determine the extent to which spatial associations occurred among districts in the concentration of dumping sites, several spatial adjacency weight matrices were built. The value of Moran's $I$ statistic varies from -1 to 1 . If adjacent spatial units are similar to one another, the value of the statistic is positive. If objects are different, the value of the statistic is negative. In the event that there is no correlation between adjacent values, the expected value is close to zero. To verify hypotheses concerning spatial autocorrelation, so-called randomization tests are performed (for the algorithm of this test, see i.e., Anselin and Bera [44]). Recent spatial studies demonstrate that the magnitude of the global Moran's I in general depends not only on the underlying correlation but also on certain heterogeneity the in individual observations $[45,46]$. However, testing procedures in situations where the usual assumption of regional or temporal homogeneity is violated call for further research. Here, the robust Lagrange Multiplier tests were applied to check the robustness of the global autocorrelation [47, 48].

Since Moran's I statistic is a global indicator and assumes homogeneity across the spatial sample, local measures are more powerful for revealing spatial regimes [49]. Anselin [50] designed a class of local indicators of spatial association (LISA), similar to the local Moran's I statistic:

$$
I_{L I S A}=\frac{n\left(x_{i}-\bar{x}\right) \sum_{j=1}^{n} w_{i j}\left(x_{j}-\bar{x}\right)}{\sum_{i=1}^{n}\left(x_{i}-\bar{x}\right)^{2}}
$$

Thirdly, the univariate Moran's indices (Eq. 3 and 4) were used to evaluate only the association between a specific variable in one area and the same variable but in nearby areas (called lagvariable), which was focused on the same variable. However, the global and local Moran's I statistics can be extended to describe spatial correlation for two variables: one variable at a location and the other different lag-variable at the nearby location. The statistics are called bivariate, respectively [51]. Therefore, in this paper, the bivariate spatial analysis is used to explore the spatial correlation, e.g., the association between the legal dumping sites in one location and the lag variable of legal dumps in nearby areas.

The research was conducted in ArcGIS (is a geographic information system for working with maps and geographic information) and GeoDa (a free software package that provides relevant functions such as mapping, exploratory spatial data analysis, and spatial regression).

\section{Results and Discussion}

\section{Temporal Changes of Dumping Site Distribution}

Numerical values presented in Table 1 indicate a general decrease in the volume of controlled landfills in Polish districts from 2009 to 2016. A total of 132 legal dumping sites per $100 \mathrm{~km}^{2}$ were recorded in 2009 . In 2016 , the number of such landfill sites was $50 \%$ less than that in 2009. The number of illegal dumping sites per $100 \mathrm{~km}^{2}$ decreased from 1,073 in 2009 to 529 in 2012. However, in 2013, when the new waste law was implemented in Poland, the number of illegal dumping sites per $100 \mathrm{~km}^{2}$ increased from 529 in 2012 to 928 in 2013. On the other hand, this year saw the most illegal dumping sites identified and removed (5,867 units per $100 \mathrm{~km}^{2}$ ). Notably, the number of illegal dumping sites in districts was nearly eightfold more than the number of legal dumping sites (Table 1). In 2016, the average area of an illegal dumping site $\left(42 \mathrm{~km}^{2}\right)$ was $5 \%$ of the area of a district ( $825 \mathrm{~km}^{2}$ for a unit), whereas the average area of a legal dumping site was $0.05 \mathrm{~km}^{2}$ per district (i.e., approximately $0.01 \%$ of the area of a district). Moreover, 51,347 tons of municipal waste were collected while closing down illegal dumping sites in LAU-1 regions in 2016 (approximately $2 \mathrm{~kg}$ waste per person, with 101,013 average population of a region).

\section{Spatial Concentration}

In the case of illegal dumping sites (2009-2010), there were a few districts with high concentration levels. Most of regions were characterized with the $L Q$ close to the weight variable's value, throughout $L Q=1.00$ (Fig. 1).

Considerable changes occurred in the number of illegal dumping sites from 2011 to 2012, indicating a strong regional concentration of the studied phenomenon, depending on the given variable category. The concentration of uncontrolled dumping sites continued to increase until the end of the study period, which was confirmed by the high values of spatial 



Fig. 1. Spatial concentration of uncontrolled dumping sites as of December 31 of each year. Source: own elaboration in ArcMap 10.6.

Gini coefficient (Fig. 4). Between 2009 and 2016, the highest concentrations were observed in districts in northern Poland of Zachodniopomorskie and Pomorskie (especially in Gdańsk city), Lubelskie (in rural areas), Podlaskie, Łódzkie, Śląskie (with the most densely populated and largest urbanized areas, due to the presence of industry), Świętokrzyskie (among forest districts), and Wielkopolskie (where due to the Polish Local Data Bank the expenditures of district budgets on municipal waste management are one of the lowest in the country, i.e., only $\$ 0.5$, compared with the $\$ 1.08$ average).
Although the concentration of uncontrolled waste sites increased from 2009 to 2016, more and more illegal dumping sites were removed (Fig. 2).

In 2011 and 2012, the $L Q$ values of most of the districts were approximately 1.00 , indicating that the process of closing illegal dumps was relatively evenly distributed in each district (see also values of Gini coefficient in the Fig. 4). The highest concentrations of removing uncontrolled dumping sites were observed in urban areas (predominantly together with their metropolitan areas - patterned metropolitan systems with an extensive urbanized suburban zone, strong
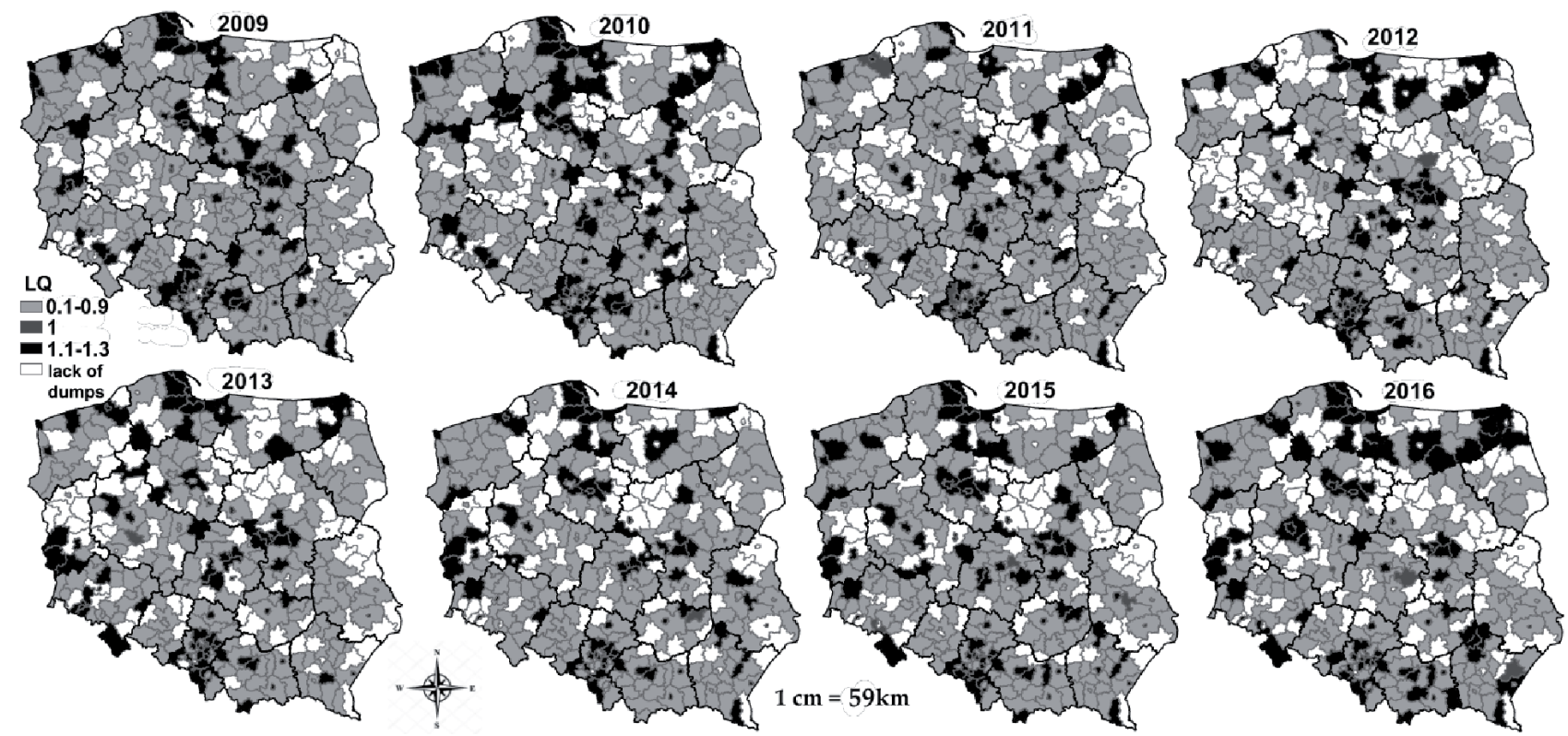

Fig. 2. Spatial concentration of uncontrolled dumping sites removed during each year.

Source: own elaboration in ArcMap 10. 

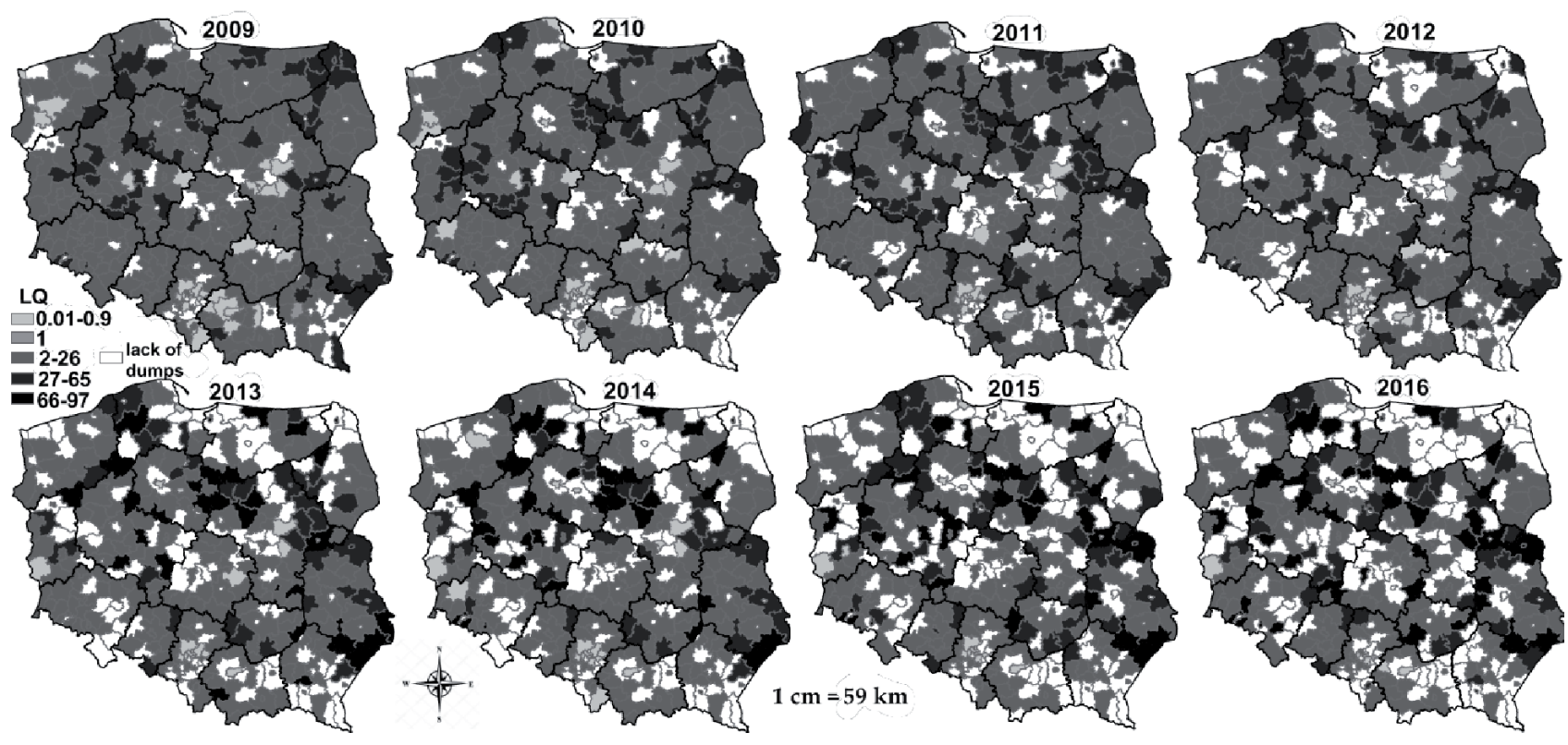

Fig. 3. Spatial concentration of controlled dumping sites in each year.

Source: own elaboration in ArcMap 10.6.

centripetal connections, [52]) and among districts located in northern Poland (Warmińsko-Mazurskie and Pomorskie), in Mazowieckie (together with Warszawa), Łódzkie, Wielkopolskie, and urban areas in densely populated Śląskie Voivodeship (where the concentration of illegal waste sites was the highest, respectively, see Fig. 1).

Finally, the concentration opening controlled dumps in districts has increased since 2013 (Fig. 3).

This indicates that between 2009 and 2012, legal dumping sites were numerous and relatively evenly distributed in each district. However, after 2 years, regional differences were gradually narrowed because guidelines of the EU landfill directive and waste framework directive (Directive 1999/31/EC on the landfill of waste) increased pressure on Polish waste management to change the disposal structures. Due to the new Polish law, waste generation should be prevented or limited in volume by recycling, and if waste

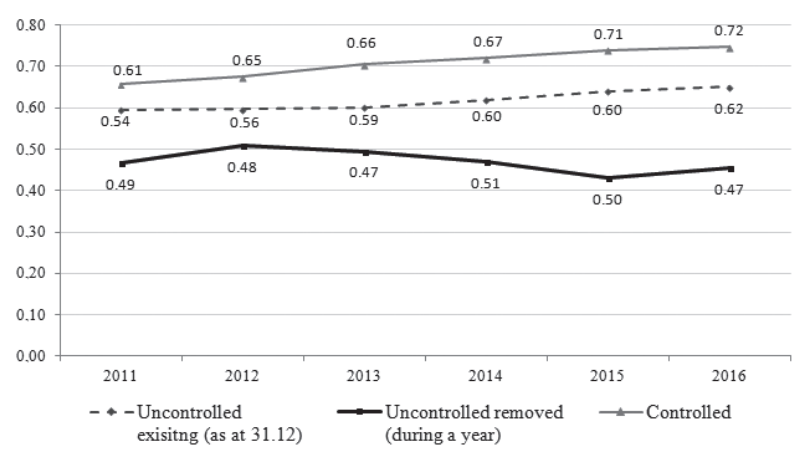

Fig. 4. Values of the spatial concentration Gini index. Source: own elaboration. has been generated, it should be recovered or disposed of. The final way of waste management is landfilling. Consequently, a large number of landfills were closed and reclaimed. After 2013, the highest number of legal landfills was identified only in Pomorskie, Mazowieckie, Wielkopolskie, and Lubelskie voivodeships. A lack of dumping sites was observed in cities and districts located in southern and northwestern Poland.

Gini coefficients fully reflected differences in the structure of dumping sites in each Polish district (Fig. 4).

Numerically, Gini indices were the highest for controlled dumping sites, and increased from 0.61 in 2009 to 0.75 in 2016, thus confirming the implementation of the Landfill Directive into Polish waste law. For example, according to the Polish Local Data Bank, approximately $45 \%$ of the controlled dumping sites in Poland were removed from 2009 to 2016 (see Section 5.1);. The Gini coefficients were also high for uncontrolled existing dumps, and increased from 0.54 in 2009 to 0.65 in 2016, indicating considerable regional diversification. On the other hand, Gini coefficients of uncontrolled removed dumping sites were the lowest (0.49 in 2009 and 0.45 in 2016). A maximum increase and maximum decrease of 0.04 in Gini coefficients indicated more symmetric distribution of dumping sites.

\section{Spatial Autocorrelation}

The number of controlled dumps showed the strongest positive spatial relationship throughout the study period (Table 2), implying a spatial dependence of legal dumping among districts. It is interesting to note that significant spatial dependencies started from the second order of adjacency and expired at 
Table 2. Moran's I spatial autocorrelation among different types of dumping sites.

\begin{tabular}{|c|c|c|c|c|c|c|c|c|c|}
\hline & & 2009 & 2010 & 2011 & 2012 & 2013 & 2014 & 2015 & 2016 \\
\hline \multirow{6}{*}{$\begin{array}{c}\text { Existing } \\
\text { uncontrolled }\end{array}$} & $\mathrm{W}_{1}$ & $0.01 *$ & $0.02 * *$ & $0.09 * *$ & -0.005 & -0.006 & -0.002 & $0.01 *$ & $0.13 * *$ \\
\hline & $\mathrm{W}_{2}$ & 0.002 & $0.01^{*}$ & $0.05^{* *}$ & 0.001 & -0.03 & $0.03 * *$ & $0.07 * *$ & $0.07 * *$ \\
\hline & $\mathrm{W}_{3}$ & -0.003 & -0.003 & $0.02 * *$ & $0.01 *$ & -0.003 & $0.02 * *$ & $0.04 * *$ & $0.05^{* *}$ \\
\hline & $\mathrm{W}_{4}$ & -0.002 & -0.002 & $0.02 * *$ & $0.01 *$ & -0.001 & $0.02 * *$ & $0.02 * *$ & $0.04 * *$ \\
\hline & $\mathrm{W}_{5}$ & -0.001 & -0.002 & $0.02 * *$ & $0.01^{*}$ & 0.001 & $0.01 * *$ & $0.01 * *$ & $0.03^{* *}$ \\
\hline & $\mathrm{W}_{6}$ & -0.001 & -0.002 & $0.02 * *$ & $0.01 *$ & -0.0008 & 0.006 & $0.01 * *$ & $0.02 * *$ \\
\hline \multirow{6}{*}{$\begin{array}{c}\text { Removed } \\
\text { uncontrolled }\end{array}$} & $\mathrm{W}_{1}$ & $0.05^{*}$ & $0.03^{*}$ & $0.04 *$ & $0.06^{* *}$ & $0.06^{* *}$ & $0.06^{* *}$ & $0.03 *$ & $0.02 *$ \\
\hline & $\mathrm{W}_{2}$ & $0.02 *$ & 0.01 & 0.01 & $0.03^{*}$ & $0.02 *$ & $0.02 *$ & 0.01 & 0.003 \\
\hline & $\mathrm{W}_{3}$ & $0.01^{*}$ & $0.01^{*}$ & 0.003 & 0.01 & 0.004 & 0.001 & 0.0003 & -0.003 \\
\hline & $\mathrm{W}_{4}$ & $0.01^{*}$ & $0.01^{*}$ & 0.001 & $0.007^{*}$ & $0.005^{*}$ & $0.005^{*}$ & -0.002 & -0.005 \\
\hline & $\mathrm{W}_{5}$ & $0.01 *$ & $0.01^{*}$ & $0.008^{*}$ & $0.009^{*}$ & $0.01 *$ & $0.007^{*}$ & 0.0002 & -0.003 \\
\hline & $\mathrm{W}_{6}$ & $0.008^{*}$ & $0.01^{*}$ & 0.002 & 0.002 & $0.006^{*}$ & -0.0004 & -0.005 & -0.006 \\
\hline \multirow{6}{*}{ Controlled } & $\mathrm{W}_{1}$ & 0.01 & -0.002 & 0.003 & 0.003 & 0.01 & 0.02 & 0.03 & 0.03 \\
\hline & $\mathrm{W}_{2}$ & $0.04 * *$ & $0.05^{* *}$ & $0.05^{* *}$ & $0.05^{* *}$ & $0.06^{* *}$ & $0.07 * *$ & $0.03 * *$ & $0.03 * *$ \\
\hline & $\mathrm{W}_{3}$ & $0.03 * *$ & $0.03 * *$ & $0.04 * *$ & $0.04 * *$ & $0.05 * *$ & $0.05 * *$ & $0.03 * *$ & $0.03 * *$ \\
\hline & $\mathrm{W}_{4}$ & $0.02 * *$ & $0.02 * *$ & $0.03 * *$ & $0.03^{* *}$ & $0.04 * *$ & $0.04 * *$ & $0.03^{* *}$ & $0.03 * *$ \\
\hline & $\mathrm{W}_{5}$ & $0.01 * *$ & $0.02 * *$ & $0.02 * *$ & $0.02 * *$ & $0.03 * *$ & $0.03 * *$ & $0.02 * *$ & $0.02 * *$ \\
\hline & $\mathrm{W}_{6}$ & 0.004 & 0.007 & $0.01^{*}$ & $0.01 *$ & $0.02 * *$ & $0.02 * *$ & $0.01 * *$ & $0.01 * *$ \\
\hline
\end{tabular}

Note: $\mathrm{W}_{n}$, where $n=1-6$ indicates the matrix at the first, second, ..., sixth order of contiguity, respectively $(* p=0.10, * * p=0.05$, $* * * p=0.01$ ). The Moran'I indices were justified by robust Lagrange Multiplier tests. The characteristics of matrices and results of robust tests are available by email.

Source: own elaboration in GeoDa.

the sixth order of contiguity. This may be a result of incorrect system solutions applied by the municipality, spatial distribution of inter-municipal bodies (that is uneven and differs clearly by voivodeship) as well as extensive distribution of communes cooperating in municipal waste management $[25,32]$. Moreover, since the implementation of the new waste law, regional distribution of dumping places gradually decreased (Fig. 3); for example, some of the units were closed down and therefore some landfills took over the disposal function of others.

According to Moran's I statistic, illegal dumping sites were also spatially autoregressive (Table 2). On average, the strongest positive and statistically significant spatial interactions identified unwanted waste sites located close to each other, i.e., across only one administrative border (Moran's I: 0.01 in 2009 and 0.13 in 2016). Accessibility to a potential illegal dumping site is affected by its distance from roads, forests, rural areas, parks, and buildings, as well as by the presence of other unwanted waste sites, which is referred to as the broken windows theory [53]. These spatial associations increased over time from 2009 to 2016 (non-significant or weak spatial dependency in 2009, 2010, and 2013) and decreased with distance (up to the sixth order of contiguity). Jakiel et al. [23] suggest that the greater the distance from a residential area, the lower the probability of finding an uncontrolled landfill.
Positive global Moran's I statistic proved the presence of clusters of districts with similar levels of dumping sites per $100 \mathrm{~km}^{2}$, according to the assumed $\mathrm{W}$ matrices $(p<0.05$; Table 2$)$. The further analysis of local spatial associations included weight matrices with the strongest global univariate spatial autocorrelation. For example, the first-order contiguity matrix $\left(\mathrm{W}_{1}\right)$ was suggested for the existing and removed illegal waste sites, and the second-order matrix $\left(\mathrm{W}_{2}\right)$ was preferred for spatial local autocorrelation analysis for legal dumps.

\section{Spatial Correlation}

The spatial analyses have suggested non-randomness in the overall spatial pattern of dumping sites in Polish districts. In this part of the research study, the local bivariate spatial analysis (LISA) was conducted, which investigates the relationship between the number of waste sites in one location and the lag factor of dumps in nearby areas.

Fig. 5 shows the results of bivariate spatial correlation for the number of illegal dumping sites in 2016 in one district and the number of controlled waste sites in 2014 in its neighbouring areas. The Moran's I of 0.10 indicates that there is an apparent association between variables. Bivariate LISA analysis as shown on the map in Fig. 4 presents the spatial distributions for these relationships. On the basis of LISA, five 

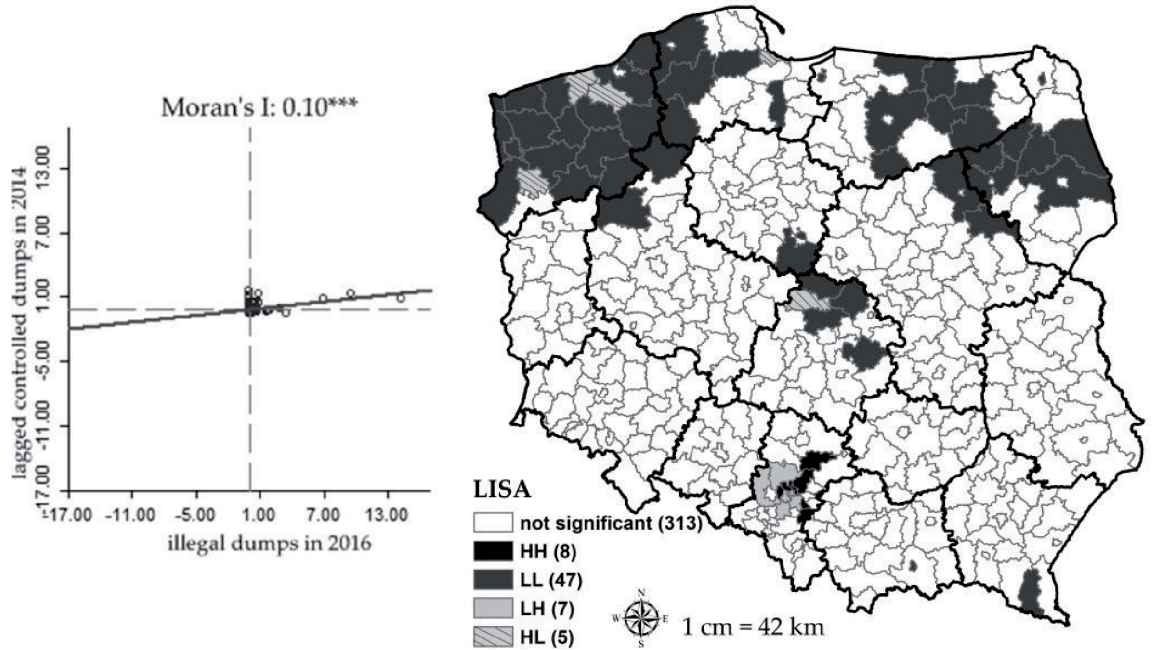

Fig. 5. Bivariate global and local spatial correlation analysis of the number of illegal and controlled waste sites in Poland.

Note: Areas with significant autocorrelation are indicated with $p \leq 0.05$, and areas with no significant autocorrelation are shown in white. High-high (HH, hot spots, e.g., areas with a high number of illegal waste sites and surrounded by similar sites) and low-low (LL, cold spots), i.e., areas with a low number of illegal waste sites and surrounded by similar sites) areas represent spatial clusters, and high-low (HL) and low-high (LH) areas represent spatial outliers. Source: own elaboration in GeoDa.

high-low entities were indicated (HL code). These districts, with the high concentration of illegal dumps, have the neighbouring areas with low concentration of controlled waste sites. Most of them are located in Zachodniopomorskie, in which 23 legal municipal landfills were closed in 2009-2016 [54]. One district is located in Pomorskie (Gdańsk city) and one in the centre of Poland in Łódzkie (the Łęczycki District, where in 2009-2016 several legal landfills were closed, and in 2018 a few arsons of recycling facilities took place) [55]. For local authorities taking action to combat the emergence of illegal dumping sites, the situation of districts in Śląskie (southern Poland) is also a worrying sign (in Fig. 5 these districts are defined as $\mathrm{HH}$ ). High-high means that the area with high concentration of illegal dumping sites is surrounded by districts with high congestion of controlled dumps. Therefore, it can be concluded that waste management policy is ineffective and the lack of legal waste sites determines the emergence of illegal dumping sites [27]. Paradoxically, there are districts in the same voivodeship where the concentration of illegal dumping sites is low, but they border upon districts with a much higher number of legal landfills (identified as low-high code, LH, Fig. 5).

In turn, in the districts of Kujawsko-Pomorskie, Wielkopolskie as well as in Suwałki and Elbląg indicated in the LISA analysis, one may notice signs of the effectiveness of the waste policy being pursued. In entities defined as high-low (HL code, see Fig. 6) there is a statistically significant spatial relationship between the number of legal waste sites in a given district and the number of illegal waste dumps in neighbouring entities


Fig. 6. Bivariate global and local spatial correlation analysis of the number of legal and illegal waste sites in Poland. Note: explanation of LISA symbols, see notes under the Fig. 5. Source: own elaboration in GeoDa. 

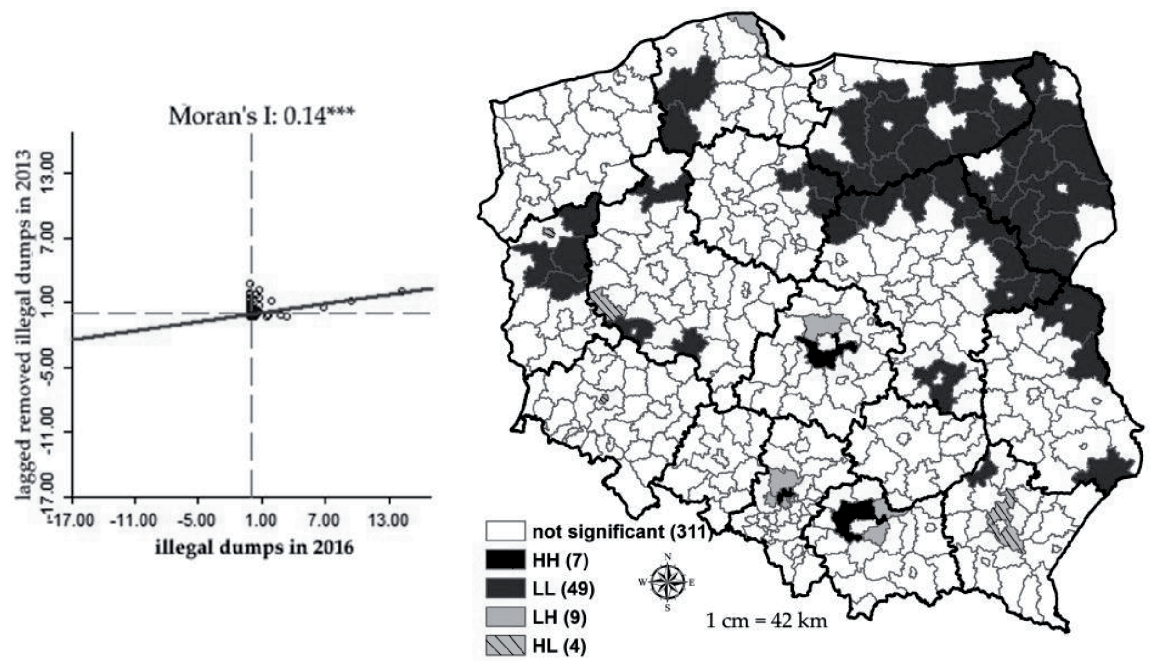

Fig. 7. Bivariate global and local spatial correlation analysis of the number of illegal and removed illegal waste sites in Poland. Note: explanation of LISA symbols, see notes under the Fig. 5. Source: own elaboration in GeoDa.

(Moran's $I: 0.22, p<0.05$ ). It is shaped in such a way that the districts with a huge number of legal dumping sites are surrounded by areas with low concentration levels of illegal dumps. However, a particularly unfavourable situation in the scope of the analyzed spatial relationship takes place in the southeastern part of the country, i.e., in districts marked with $\mathrm{HH}$ and LH symbols located in the following voivodeships: Śląskie, Małoposkie, and Lubelskie (Fig. 6).

Fig. 7 shows the results of significant bivariate spatial correlation for a number of existing and removed illegal waste sites in districts (Moran's I is $0.14, p<0.05$ ). The consequence of the ineffectiveness of the waste policy being implemented are districts ( $\mathrm{HH}$ and $\mathrm{HL}$ code, Fig. 7) in which the number of illegal waste sites is much higher than the average, and paradoxically they border districts in which the scale of removal of illegal dumps increases. Such a situation takes place in districts located in Łódź (central Poland), Małopolskie and in Śląskie voivodeships (south of the country) as well as in Gorzów Wielkopolski and Legnica. At the same time, in Wielkopolskie and Podkarpackie voivodships there are entities identified as high-low in the LISA analysis (HL, Fig. 7), which are characterized by a large number of illegal dumps, but are surrounded by districts where the effectiveness of detection and removal of illegal dumps is small. The results of the spatial correlation test indicate entities (LH code) with low levels of illegal dumping concentration which are surrounded by districts with a huge number of removed illegal dumps per $100 \mathrm{~km}^{2}$ in 2013 (Fig. 7). It can therefore be argued that the implemented waste policy model is effective.

\section{Conclusions}

Until 2013, the waste management system did not include the entire Polish population, i.e., some people did not use or pay for a door-to-door waste collection service, leading to improper or illegal waste disposal, such as burning garbage in households [25]. Important changes in the legal framework were made on July 1, 2013, which made municipalities the owners of the municipal solid waste generated in their jurisdiction and made them responsible for waste collection and treatment. Although the importance of waste segregation increased, the living standards of inhabitants as well as the avoidance of paying disposal fees at waste management sites, under the new system, resulted in an increase of illegal waste disposal among districts.

The results of this study showed that the distribution of dumping sites in Poland is not random. During the study period, $82 \%$ of Polish districts (311 out of 380 units) contained illegal dumping sites. The concentration of uncontrolled and controlled dumping sites increased from 2009 to 2016. Fortunately, illegal dumping sites were closed quite evenly among districts from 2009 to 2016. Moreover, the identification of spatial dependencies provided additional insights into the dynamics of dumping inequality. Positive Moran's I statistic proved the presence of clusters of districts with similar levels of dumping sites. Because of the presence of illegal dumping sites, the strongest significant spatial interactions appeared locally, i.e., across only one administrative border, from one district to another. Moreover, the local bivariate spatial analysis (LISA) investigated the relationship between the number of waste sites in one location and the lag factor of dumps in nearby areas. The results of the LISA showed districts in which: 1) the occurrence of illegal dumping sites was associated with an insufficient number of legal waste sites in neighbouring entities, 2) the concentration of legal dumping sites determined the lack of illegal waste sites in neighbouring entities, and 3) despite the intensification of activities in removing illegal dumps in the district, in neighbouring districts there was an 
increase in the number of unauthorised dumping areas. This is especially important because of the identification of locations that could potentially be monitored in the future to prevent any waste disposal and that should be under the control of the local authorities.

Although this study revealed the spatial aspects of variability across dumping sites in Poland, many areas need further research, both from theoretical and methodological perspectives. For example, spatial econometric techniques can be applied, i.e., combining spatial processes and determinants to clarify the mechanisms of spatial concentration of dumping sites and dependencies among districts. Moreover, we need to use LISA maps in a different way, i.e., by combining different spatial weighting schemes to minimize the effect of their arbitrary selection as well as studying the phenomenon more accurately and effectively. In addition, the role of urban and rural areas in the number of dumping sites can enrich the analysis. Further investigation is also needed to explore regional heterogeneity of waste sites and to understand the reasons for geographical clustering and uneven distribution of disposals among districts. Finally, the applicability of suggested methods needs to be tested in other countries.

To sum up, it is no accident that since the beginning of 2018, 70 Polish waste dumping sites have been set on fire. Countries such as UK and Germany, for which it is still cheaper to export waste than to recycle it at home, have been exporting waste to Poland. As a result, around 12,000 tons every year are being imported to Poland by the country's so-called 'trash mafia' - a group of landfill operators whose primary line of business lies in waste recycling, but who often end up burning the waste instead [56].

\section{Appendix}

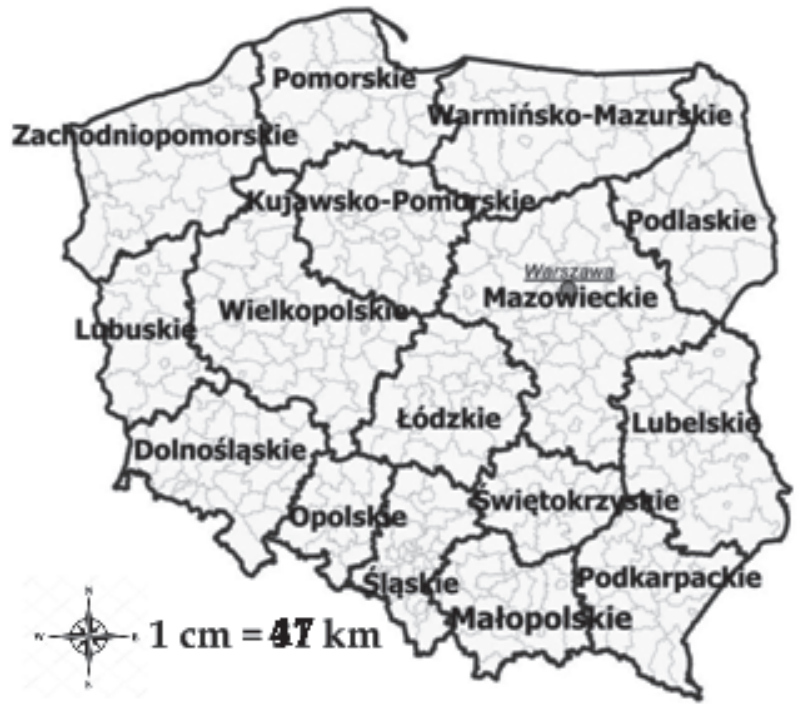

Fig. A.1. Map of Polish NUTS-2 (voivodeships)

\section{Conflict of Interest}

The authors declare no conflict of interest.

\section{References}

1. GOTTEL B. Pole position: the state of waste management in Poland. Isonomia. 2014. Available online: 2014, http:// www.isonomia.co.uk/?p=3410 (accessed on 10 January 2019).

2. KRÓL S. Illegal landfill sites in Poland. World Scientific News, 48, 164, 2016.

3. WILEGOSIŃSKI G., NAMIECIŃSKA O. Spalarnie odpadów komunalnych - perspektywa roku 2020. Nowa Energia, 2, 2016. Available online: https://www.cire.pl/ pliki/2/13888artgrzegorzwielosinski.pdf (accessed on 13 January 2019).

4. MINISTRY OF THE ENVIRONMENT, 2018. Available online: https://www.mos.gov.pl/srodowisko/edukacjaekologiczna/badania/badania-swiadomosci-ekologicznej/ (accessed on: 16 September 2018).

5. MINISTRY OF THE ENVIRONMENT, 2017. Available online: https://www.mos.gov.pl/fileadmin/user_upload/ mos/Aktualnosci/2017/grudzien_2017/Raport_z_badania_ dot._gospodarki_odpadami_2017_r._pdf (accessed on: 16 September 2018).

6. HOLLINS O., LEE P., SIMS E., BERTHAM O., SYMINGTON H., BELL N., PFALTZGRAFF L., SJÖGREN P. Towards a circular economy-Waste management in the EU, STOA, Brussels. 2017. Available online: $\quad$ www.europarl.europa.eu/RegData/etudes/.../ EPRS_STU\%282017\%29581913_EN.pdf (accessed on 10 January 2019).

7. BIEGAŃSKA J., CIUŁA J. Integrated waste management in Poland as an element of sustainable development [in Polish]. Archiwum Gospodarki Odpadami i Ochrony Środowiska, 13 (1), 51, 2011.

8. TASAKI T., KAWAHATA T., OSAKO M., MATSUI Y., TAKAGISHI S., MORITA A., AKISHIMA S. A GISBased Zoning of Illegal Dumping Potential for Efficient Surveillance. Waste Management, 27 (2), 256, 2007.

9. SULTAN M., WAHEED S., ALI U., SWEETMAN A. J., JONES K. C., MALIK R. N. Insight into occurrence, profile and spatial distribution of organochlorine pesticides in soils of solid waste dumping sites of Pakistan: Influence of soil properties and implications for environmental fate. Ecotoxicology and Environmental Safety, 170, 195, 2019.

10. TRIASSI M., ALFANO R., ILLARIO M., NARDONE A., CAPORALE O., MONTUORI P. Environmental Pollution from Illegal Waste Disposal and Health Effects: A Review on the "Triangle of Death". International Journal of Environmental Research and Public Health, 12, 1216, 2015.

11. CALÒ F., PARISE M. Waste Management and Problems of Groundwater Pollution in karst Environments in the Context of a Post-Conflict Scenario: The Case of Mostar (Bosnia Herzegovina). Habitat International, 33, 63, 2009.

12. SANCHEZ R.A. Water Quality Problems in Nogales, Sonora. Environmental Health Perspectives, 103, 93, 1995.

13. CRITTO A., CARLON C., MARCOMINI A. Characterization of Contaminated Soil and Groundwater Surrounding an Illegal Landfill (S. Giuliano, Venice, Italy) by Principal Component Analysis and Kriging. Environmental Pollution, 122 (2), 235, 2003. 
14. URICCHIO V.F., PALMISANO V.N., LOPEZ N., BRUNO D.E. A Centralized Management Data to Prevention of Environmental Crimes Fight: The Altamura Case. Paper presented at the 2010 IEEE Workshop on Environmental, Energy, and Structural Monitoring Systems, Taranto, Italy September 9 .

15. APOSTOL L., MIHAI F.C. The Process of Closing Down Rural Landfills. Case Study: Neamt, County. Present Environment and Sustainable Development, 5 (2), 167, 2011.

16. BRANDT A. Illegal Dumping as an Indicator for Community Social Disorganization and Crime. 2017. Available online: https://scholarworks.sjsu.edu/cgi/ viewcontent.cgi?article $=8382 \&$ context $=$ etd_theses (accessed on: 20 February 2019).

17. OECD. Environmental Performance Review of Poland. 2015. Available online: https://www.oecd.org/environment/ country-reviews/OECD\%20EPR\%20Poland $\% 202015 \% 2$ 0Highlights\%20EN.pdf (accessed on: 23 February 2019).

18. BOER DEN E., JĘDRCZAK A., KOWALSKI Z., KULCZYCKA J., SZPADT R. A review of municipal solid waste composition and quantities in Poland. Waste Management, 30 (3), 369, 2010.

19. FILIPIAK P., DUSZA E., KUGLARZ K., KUŹNIAR J., ĆWIRKO K. Wpływ „dzikich wysypisk” śmieci na terenie dzielnicy Warszewo (Szczecin) na środowisko naturalne. SKN Ochrony Środowiska, Akademia Rolnicza w Szczecinie, 9, 2007.

20. KASZUBKIEWICZ J., GAŁKA B., KAWAŁKO D. Impact of legal and illegal waste dumps on the surrounding soils in the Jelenia Góra and Wrocław districts [in Polish]. Roczniki Gleboznawcze, 62 (2), 179, 2011.

21. BRACH M., WIŚNIEWSKI M. Spatial aspects of illegal dumping sites of municipal wastes in the Stankowizna forest range [in Polish]. Roczniki Geomatyki, 10 (5), 37, 2012.

22. MALINOWSKI M., WOLNY-KOŁADKA K., JASTRZĘBSKI B. Characteristics of Illegal Dumping Sites - Case Study. Watercourses. Infrastructure and Ecological of Rural Areas, 4, 1475, 2015.

23. JAKIEL M., BERNATEK-JAKIEL A., GAJDA A., FILIKS M., PUFELSKA M. Spatial and temporal distribution of illegal dumping sites in the nature protected area: the Ojców National Park, Poland. Journal of Environmental Planning and Management, 60, 1, 2018.

24. KOLANOWSKI B., WIŚNIEWSKI J. Assessment of the size and position of wild dumps in the White Forest in the municipality of Ostrow Mazowiecka classified as a Natura 2000 [in Polish]. Infrastruktura i Ekologia Terenów Wiejskich, 2 (I), 99, 2012.

25. MACIAS A., PINIARSKI W. Municipal Solid Waste Management Problems on a Local Scale: A Case Study from Rural Poland. Polish Journal of Environmental Studies, 25 (4), 1623, 2016.

26. MÉAR Y., POIZOT E., MURAT A., BERYOUNI K., BAUX N., DAUVIN J-C. Improving the monitoring of a dumping site in a dynamic environment. Example of the Octeville site (Bay of Seine, English Channel). Marine Pollution Bulletin, 129 (2), 425, 2018.

27. COUNCIL OF MINISTRY. National Waste Management Plan 2022, Annex to the Resolution No 88 of the Council of Ministers of 1 July 2016 (item 784), 2016, Warsaw. Available online: https://sip.lex.pl/aktyprawne/mp-monitor-polski/krajowy-plan-gospodarkiodpadami-2022-18334576 (accessed on 10 January 2019).
28. Journal of Laws of 2013, item 21 with amendments; further referred to as the Act on Waste of 2012; as far as the new Act on Waste of 2012 is concerned.

29. RAKOCZY B. Organisation of municipal waste management in Polish law. Polish Yearbook of Environmental Law, 4, 2014.

30. ALWAELI M. An overview of municipal solid waste management in Poland. The current situation, problems and challenges. Environment Protection Engineering, 41 (4), 181, 2015

31. CYRANKA M., JURCZYK M., PAJĄK T. Municipal Waste-to-Energy plants in Poland-current projects. Available online: https://www.e3s-conferences.org/ articles/e3sconf/abs/ 2016/05/contents/contents.html?mb=0 (accessed on: 12 January 2019).

32. KOŁSUT B. Inter-Municipal Cooperation in Waste Management: The Case of Poland. Quaestiones Geographicae, 35 (2), 91, 2016.

33. WOJTCZAK A. Selektywnie o PSZOK-ach. Dwa lata po „rewolucji śmieciowej. 2015. Available online: http:// portalkomunalny.pl/selektywnie-o-pszok-ach-dwa-latapo-rewolucjismieciowej-323428/2/ (accessed on: 12 January 2019).

34. ANTCZAK E. Economic Development and Transfrontier Shipments of Waste in Poland-Spatio-Temporal Analysis. Comparative Economic Research, 17, 6, 2014.

35. TAŁAŁAJ I. A. The influence of chosen socio-economical factors on change of waste quantity in podlaskie province. Inżynieria Ekologiczna, 25, 146, 2011 [In Polish].

36. KLOSTERMAN R.E., BRAIL R.K., BOSSARD E.G. Spreadsheet Models for Urban and Regional Analysis; New Brunswick: NJ Transaction, 1993.

37. BRANTINGHAM P., BRANTINGHAM P. Mapping crime for analytic purposes: Location quotients, counts and rates. In Crime Mapping and Crime Prevention; WEISBURD D., MCEWEN T. Eds., Crime Prevention Studies, 8 , 1998. Available online: http://citeseerx.ist.psu. edu/viewdoc/download; jsessionid=3F52F5551E906BBF50 EB92A21669E232?doi=10.1.1.375.7657\&rep=rep1\&type $=p$ df (accessed on: 12 January 2019).

38. SUCHECKI B. Eds. Spatial Econometris [in Polish]; C.H. Beck: Warszawa, Poland, 33, 2010.

39. KRUGMAN P.R. Geography and Trade. The MIT Press: Cambridge, Massachusetts, 1991.

40. KIM Y., BARKLEY D.L., HENRY M.S. Industry Characteristics Linked to Establishments Concentration in Nonmetropolitan Areas. Journal of Regional Science, 40 (2), 2000.

41. RUIZ-VALENZUELA R., MORENO-SERRANO R., VAYÁ-VALCARCE E. Has concentration evolved similarly in manufacturing and services? A sensitivity analysis. AQR Research Group. 2007. Available online: https://core.ac.uk/download/pdf/43549201.pdf (accessed on: 12 January 2019).

42. GINI C. Measurement of Inequality of Incomes. The Economic Journal, 31 (121), 124, 1921.

43. LESAGE J., PACE K. Introduction to Spatial Econometrics; CRC Press: Boca Raton, FL, USA, 2009.

44. ANSELIN L., BERA A. Spatial dependence in linear regression models with an introduction to spatial econometrics. In Handbook of Applied Economic Statistics; ULLAH A., GILES D.E.A., DEKKER M., Eds.; NY: CRC Press, 2371998.

45. ZHANG T., LIN G. On Moran's I coefficient under heterogeneity. Computational Statistics \& Data Analysis, 95, 83, 2016. 
46. JACKSON M.C., HUANG L., XIE Q., TIWARI R.C. A modified version of Moran's $I$. International Journal of Health Geographics, 9 (33), 1, 2010.

47. ANSELIN L., BERA A., FLORAX R., YOON M. Simple diagnostic tests for spatial dependence. Regional Science and Urban Economics, 26, 77, 1996.

48. FRANZESE R. J., HAYS J., C. Testing for SpatialAutoregressive Lag versus (Unobserved) Spatially Correlated Error-Components, 2014. http://myweb.uiowa. edu/fboehmke/shambaugh 2014/papers/Franzese_Hays IOWA14.pdf (accessed on: 22 February 2019).

49. ORD J. K., GETIS A. Local Spatial Autocorrelation Statistics: Distributional Issues and an Application. Geographical Analysis, 27 (4), 286, 1995.

50. ANSELIN L. Local Indicators of Spatial Association LISA. Geographical Analysis, 27 (2), 93, 1995.

51. ANSELIN L. Spatial Econometrics: Methods and Models; Springer: Dordrecht, Netherlands, 1988.

52. KOCIUBA D. Metropolises and metropolitan areas in Poland: problems of classification and delimitation. In Natural Science; DÓBROKA M., BIKFALVI P. Eds.; Conference: $7^{\text {th }}$ International Conference of
PhD Students; At: University of Miskolc, Hungary, 81, 2010.

53. KELLING G.L., WILSON J.Q. Broken windows: the police and neighborhood safety. Atlantic Monthly, 249 (3), 29, 1982.

54. Appendix No. 1 to the Waste Management Plan for the Zachodniopomorskie Voivodeship for the years 2012-2017, taking into account the perspective for 2018-2023 [in Polish]. List of landfill sites and storage sites for waste destined for land reclamation Available online: http://www.srodowisko.wzp.pl/sites/default/files/ files/23975/06962900_1412988184_Wykaz_skadowisk_i kwater_do_skadowania_odpadw_przeznaczonych_do_ rekultywacji.doc (accessed on: 16 January 2019).

55. VOIVODESHIP INSPECTORATE OF ENVIRONMENTAL PROTECTION, 2013. Available online: https://www. wios.lodz.pl/files/docs/r09xviixodpady.pdf (accessed on: 16 January 2019).

56. MINISTRY OF ENVIRONEMENT, 2018, Available online: https://www.mos.gov.pl/aktualnosci/szczegoly/ news/pozary-skladowisk-stop-patologiom-w-gospodarceodpadami/ (accessed on: 16 January 2019). 
